\title{
Recent emergence of CAT5 tropical cyclones in the South Indian Ocean
}

\section{AUTHOR: \\ Jennifer Fitchett ${ }^{1}$ (iD \\ AFFILIATION: \\ ${ }^{1}$ School of Geography, Archaeology and Environmental Studies, University of the Witwatersrand, Johannesburg, South Africa}

\section{CORRESPONDENCE TO: Jennifer Fitchett}

EMAIL: jennifer.m.fitchett@gmail.com

DATES:

Received: 12 Feb. 2018

Revised: 16 July 2018

Accepted: 21 Aug. 2018

Published: 27 Nov. 2018

\section{KEYWORDS:}

hurricane; category 5; climate change; sea surface warming; southern hemisphere

\section{HOW TO CITE:}

Fitchett J. Recent emergence of CAT5 tropical cyclones in the South Indian Ocean. S Afr J Sci. 2018;114(11/12), Art. \#4426, 6 pages. https://doi. org/10.17159/sajs.2018/4426

\section{ARTICLE INCLUDES: \\ $\times$ Supplementary material \\ $\times$ Data set}

FUNDING:

Society of South African Geographers (c) 2018. The Author(s). Published under a Creative Commons Attribution Licence.
The IBTrACS global best track data set endorsed by the World Meteorological Organization provides a valuable global record of tropical cyclone genesis, track and intensity, and spans 1842 to the present. The record is significantly more robust from the late 1970s onwards, as it is supported by satellite imagery. These records indicate that the first tropical cyclone in the South Indian Ocean to intensify to CAT5 status did so in 1994. This date is significantly later than the first CAT5 storms recorded in the IBTrACS database for the Atlantic Ocean (1924) and the North Pacific (1951) recorded from ship records, and half a decade later than those of the North Indian Ocean (1989) and South Pacific (1988), captured from satellite imagery. Following this late emergence, in the period 1990-2000, eight CAT5 tropical cyclones were recorded for the South Indian Ocean. A further four have been recorded for the period 2010-2015. This recent emergence of tropical cyclones attaining category five intensity in the South Indian Ocean is of significance for the forecasting of tropical cyclone landfall and the anticipation of storm damage for the developing economies that characterise the region. Although an increase in tropical cyclone intensity is frequently projected under global climate change scenarios, the dynamics for the South Indian Ocean have remained poorly understood. Notable are early results indicating an increased frequency and poleward migration of these CAT5 storms, concurrent with a poleward migration in the position of the $26.5^{\circ} \mathrm{C}, 28^{\circ} \mathrm{C}$ and $29^{\circ} \mathrm{C}$ sea surface temperature isotherms in the South Indian Ocean.

\section{Significance:}

- $\quad$ Category 5 tropical cyclones, the strongest category of storms, have only recently emerged in the South Indian Ocean. Since 1989, their frequency of occurrence has increased. This increase poses a heightened risk of storm damage for the South Indian Ocean Island States and the countries of the southern African subcontinent as a result of the strong winds, heavy rainfall and storm surges associated with these storms, and the large radial extent at category 5 strength.

\section{Introduction}

An increased frequency and intensity of extreme weather events is cited often as one of the most dangerous impacts projected under anthropogenic-induced climate change. ${ }^{1-3}$ Increases in the intensity and frequency of heatwaves ${ }^{4}$, precipitation ${ }^{5}$ particularly in flood events ${ }^{2}$, and tornadoes ${ }^{6}$ have been recorded over the past five decades, and are projected to continue under even modest emission scenarios. However, despite both atmospheric and sea surface warming over the past century ${ }^{7}$, historical analysis has demonstrated that tropical cyclone numbers have not increased for many regions in the world ${ }^{8,9}$. Climate models similarly project local decreases, rather than an increase in the numbers of tropical cyclones developing or making landfall in the forthcoming century. ${ }^{10}$ This pattern is argued to be a consequence of a strengthening of atmospheric factors that inhibit tropical cyclone formation ${ }^{9,10}$, most significant of which is an increase in vertical shear, caused by an expansion of the Hadley cell and a subsequent displacement of the subtropical jet stream ${ }^{10-12}$. The interaction between the warming climate and the ocean-atmospheric relationships responsible for encouraging or preventing tropical cyclone genesis lead to further debate regarding geographical changes in the occurrence of these storms. For certain ocean basins, a poleward shift in tropical cyclones, and in particular their landfall, has been observed, and a number of climate models forecast a continued poleward displacement of these systems under even the lowest carbon emission scenarios. ${ }^{8,10,13}$ However, these results are contested by subsets of the historical record that would indicate an equatorward trajectory of the genesis latitude of these storms. ${ }^{9}$

Greater consensus exists regarding increasing intensities of tropical cyclones globally, both within the historical record and in modelled climate projections. This increase in storm intensity includes the maximum intensity that any given tropical cyclone will attain, the number of high intensity tropical cyclones forming (Saffir Simpson category 3-5: CAT3-CAT5), and the frequency of landfall of high intensity storms..$^{11,14,15} \mathrm{~A}$ number of studies have concluded that CAT3 and CAT4 storms, in particular, have increased in frequency globally, and are likely to continue to do so. ${ }^{15}$ However, recent reanalyses argue that while the percentage of the most intense CAT4 and CAT5 storms are increasing in number, the frequency demonstrates a decline over the past 15 years. ${ }^{16}$ Despite this focus on high intensity storms, the changing dynamics in the most intense storms over the past three decades remain poorly documented, amongst efforts to understand the broader scale implications of climate change on the formation of all tropical cyclones. ${ }^{11}$

Research on tropical cyclones in the South Indian Ocean has largely been restricted to the western half of the basin, with a particular focus on the landfall of these storms in Madagascar and Mozambique.,9,17-20 Many of these studies have relied on storm track data to determine spatial and temporal patterns in tropical cyclone genesis and landfall. ${ }^{8,18,21} \mathrm{~A}$ significant focus has been placed on determining factors influencing the inter-annual variability, both in the number of storms and their geographic location within the ocean basin, highlighting the significant role of El Niño Southern Oscillation, Quasi-Biennial Oscillation, Indian Ocean Dipole and Madden-Julian Oscillation. $8,19-22$ Because of the socio-economic vulnerability within the region, research on South Indian Ocean tropical cyclones 
has included the considerable infrastructural and economic costs associated with storm damage. 18,23,24 $^{1}$

This study reflects on the emergence of tropical cyclones in the IBTrACS record for the South Indian Ocean in 1994, and the changing dynamics of these storms over the past two decades, including changes in the number of CAT5 storms, the latitudinal positions of the storms, and the underlying sea surface temperatures as drivers of cyclogenesis.

\section{Methods}

Storm track records for the South Indian Ocean were explored using the NOAA Unisys IBTrACS record (https://www.ncdc.noaa.gov/ibtracs/ index.php? name =ibtracs-data). The data were explored for the period commencing on 1 June 1970 to avoid issues of data heterogeneity for earlier records which were compiled from ship logs, coastal records and a sparse distribution of aerial reconnaissance data, rather than satellite imagery used from 1970 onwards. ${ }^{8,25}$ The compiled record terminated in 2015. The Unisys advanced filter tool was used to isolate all storms that were classified as CAT5 to determine the total decadal count of storms in each category, and the year of the first record of CAT5 storms in each ocean basin. The wind speed and central pressure of each CAT5 storm were checked in the Unisys record for the time period for which each storm was classified at CAT5 to ensure that no miscategorisation had occurred. For each storm that had attained CAT5 strength, the latitudes and longitudes of the conversion from tropical storm to CAT1 tropical cyclone, of the conversion from CAT4 to CAT5 tropical cyclone, and of the downgrade from CAT5 storm to CAT4 or lower were manually extracted together with the date of each event. The latitudes of the conversion into and dissipation from category 5 was plotted for each storm relative to the month and year of the respective events, with timetrend calculated using linear regression.

Sea surface data were obtained from the NOAA Extended Reconstructed SST V4 GrADS images (https://www.esrl.noaa.gov/psd/data/gridded/ data.noaa.ersst.html). Images were constrained geographically for the South Indian Ocean, between $0-30^{\circ} \mathrm{S}$ and $30-120^{\circ} \mathrm{E}$, with sea surface isotherms plotted at $0.5^{\circ} \mathrm{C}$ intervals. Composite plots were calculated from mean annual sea surface temperature isotherms for a long-term mean spanning 1950-2015, for decadal means for the period 19702009 , and for the most recent half decade of tropical cyclone storm track data, 2010-2015. From these plots, the $26.5^{\circ} \mathrm{C}$ and $28^{\circ} \mathrm{C}$ isotherms were extracted and re-plotted to explore trends in isotherm shift of the period 1970-2015. From these plots the rate of change in the position of each isotherm was calculated at $10^{\circ}$ longitude intervals, and averaged for the ocean basin. Weekly mean sea surface isotherm plots were obtained from NOAA V2 sea surface temperature record (https://www. esrl.noaa.gov/psd/data/gridded/data.noaa.oisst.v2.html) for the dates of each of the CAT5 tropical cyclones identified from the IBTrACS record. Two plots were generated for each time period: the first geographically constrained by the coordinate position of the storm from conversion to CAT1 through to the location of dissipation from CAT5 and the second for the entire ocean basin. From these plots, the sea surface temperature on the date and at the geographical position of the storm track on conversion to CAT1 storm, and conversion to and dissipation from CAT5 storm were extracted, together with the mean latitudinal position of the $28^{\circ} \mathrm{C}$ isotherm for the South Indian Ocean basin.

\section{Results}

The first tropical cyclone classified as attaining CAT5 intensity in the South Indian Ocean is recorded in the IBTrACS record for February 1994. This date is considerably later than the first CAT5 tropical cyclones recorded in the same database for the Atlantic Ocean (1924) and the North Pacific (1951), which would have been detected from ship or coastal records. It is also half a decade later than the first CAT5 tropical cyclones recorded for the North Indian Ocean (1989) and South Pacific (1988) in the IBTrACS database. Although it could be argued that CAT5 tropical cyclones in regions of lower population density may have gone unnoticed in the early 19th century, the latter two records would have detected them by satellite imagery that provides a more globally equivalent database for all ocean basins from the 1970s onwards.
While this record has been improved by direct monitoring through geostationary satellites ${ }^{16}$, it is unlikely that all CAT5 storms went undetected prior to this advancement. Thereafter, four CAT5 tropical cyclones were recorded for the decadal periods 1990-1999 and 2000-2009. For the remaining 5 years captured in the data set from 2010 to 2015, a further four CAT5 storms are recorded. This recording was followed by the CAT5 tropical cyclone Fantala in April 2016. ${ }^{26} \mathrm{~A}$ sustained occurrence of CAT5 tropical cyclones has thus been experienced following the late initiation of these very intense storms, with a slight yet statistically insignificant increase in frequency, particularly since 2010. Further monitoring of these storms should be conducted to enable a data set sufficiently large for statistical significance in trends to be determined.

The 12 CAT5 tropical cyclones recorded for the South Indian Ocean do not provide a sufficient sample size for statistically significant time trends to be detected. However, the latitudinal positions of the storm track at the time of conversion to and dissipation from CAT5 intensity both demonstrate a mean poleward trend over the period 1994-2015 (Figure 1). Notably this trend includes three of the four CAT5 tropical cyclones in the period 2010-2015 escalating to the highest strength at latitudes poleward of $16^{\circ} \mathrm{S}$, and the two 2015 storms intensifying to CAT5 poleward of $17.5^{\circ} \mathrm{S}$. The trend, although statistically insignificant for both intensification and dissipation, tentatively represents a poleward trajectory in CAT5 tropical cyclone intensification at a rate of $0.003^{\circ}$ decade $(\sim 0.33 \mathrm{~km} /$ decade), and dissipation at a more rapid rate of $0.004 \%$ decade $(\sim 0.44 \mathrm{~km} /$ decade).
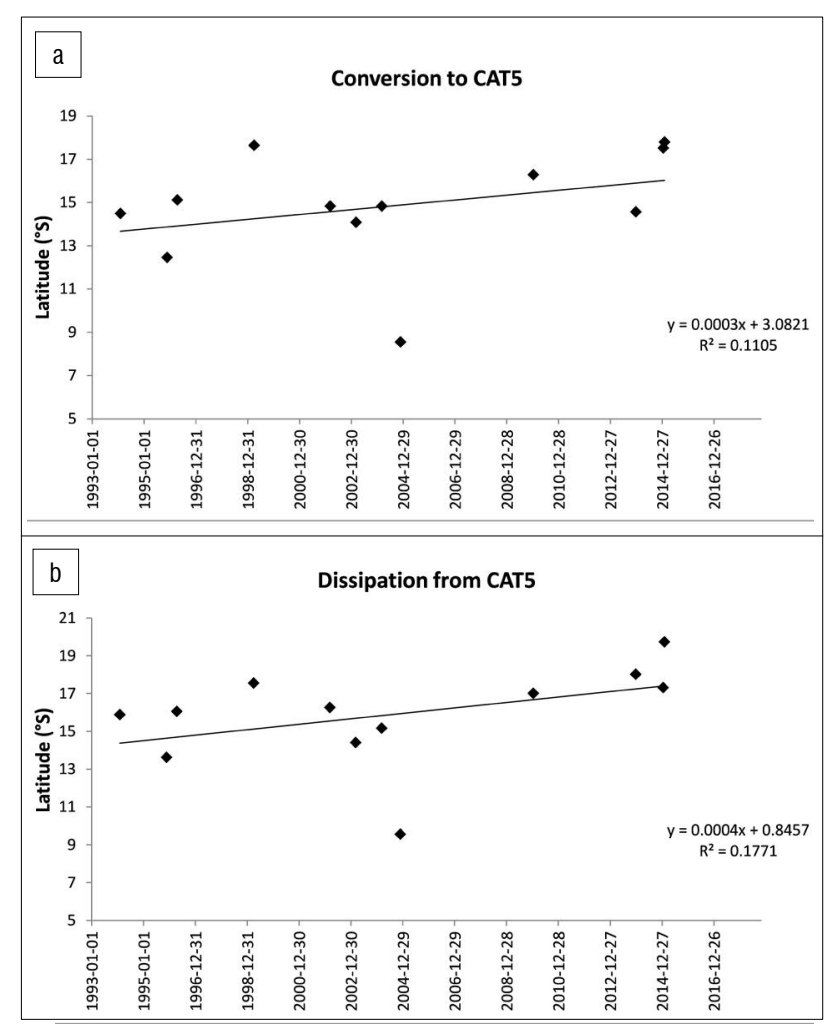

Figure 1: Latitudinal position of each CAT5 tropical cyclone storm track at the point of (a) intensification to and (b) dissipation from category 5 conditions.

The poleward shifts in the position of the storm track at the points of intensification to and dissipation from CAT5 occur concurrently with a poleward shift in the $26.5^{\circ} \mathrm{C}$ sea surface temperature isotherm in the South Indian Ocean (Figure 2). This concurrence is significant because of the requirement for $26.5^{\circ} \mathrm{C}$ sea surface temperatures for the cyclogenesis of tropical cyclones. The shift occurs at a mean rate of $0.068 \%$ year $(0.68 \%$ decade) poleward for the ocean from a mean latitude of $\sim 16^{\circ} \mathrm{S}$ to $\sim 18^{\circ} \mathrm{S}$ over the period $1970-2015$, with a more pronounced shift for the western half of the basin at a rate of $0.087^{\circ} \%$ year $\left(0.87^{\circ} /\right.$ decade). For the majority of the ocean basin, this poleward 
shift is progressive decade on decade. However, between $50^{\circ} \mathrm{E}$ and $65^{\circ} \mathrm{E}$, a reversal in this trend occurs for the decade 1990-1999 with the mean $26.5^{\circ} \mathrm{C}$ isotherm positioned north of the isotherm for the decade 1980-1989. The poleward shift resumes for the periods 2000-2009 and 2010-2015, but the deviation for 1990-1999 is notable given the emergence of the first CAT5 tropical cyclone in 1994 at a longitude of $58^{\circ} \mathrm{E}$. The slowest latitudinal shift in the $26.5^{\circ} \mathrm{C}$ is recorded for the Mozambique Channel, albeit with all isotherm positions located poleward of those for the remainder of the ocean basin. Across the ocean basin, the most rapid isotherm shift experienced was for the shortest period, from 2010 to 2015 .

Although the threshold of $26.5{ }^{\circ} \mathrm{C}$ for sea surface temperatures is required for the genesis of tropical cyclones, the intensification of these storms requires additional energy supply, predominantly through latent heat. Such intensification also requires the limitation of factors that hinder cyclogenesis, most notably vertical shear. The sea surface temperature for the date and latitude of conversion from tropical storm to CAT1 tropical cyclone for all of these storms was higher than $27^{\circ} \mathrm{C}$, and was higher than $27.5^{\circ} \mathrm{C}$ in 8 of the 12 storms. For 9 of the 12 storms, the sea surface temperature was warmer at the point of intensification to CAT1 than at intensification to CAT5, and for all the storms, the sea surface was either the same or cooler at the point of dissipation from CAT5. A notable characteristic of all storms was that during the period of their activity, the $28^{\circ} \mathrm{C}$ isotherm for the South Indian Ocean was positioned poleward of $9^{\circ} \mathrm{S}$, and the $29^{\circ} \mathrm{C}$ isotherm poleward of $3^{\circ} \mathrm{S}$. This position is relative to a long-term 1950-2015 mean position of the $28^{\circ} \mathrm{C}$ isotherm at $7^{\circ} \mathrm{S}$. For the $29^{\circ} \mathrm{C}$ isotherm, there is no longterm 1950-2015 mean position in the South Indian Ocean, with the first appearance of this isotherm in decadal means recorded for 1990-1999, notably coinciding with the first CAT5 tropical cyclone. Both the $28^{\circ} \mathrm{C}$ and $29^{\circ} \mathrm{C}$ isotherms demonstrate poleward shifts over the period 1970 2015 , with the shift in the $28{ }^{\circ} \mathrm{C}$ isotherm occurring significantly more rapidly than the shift in the $26.5^{\circ} \mathrm{C}$ isotherm.

\section{Discussion}

This study reveals two important findings regarding the changing characteristics of intense tropical cyclones in the South Indian Ocean. Firstly, prior to 1994, no tropical cyclones in the South Indian Ocean were classified, by the IBTrACS record, as having attained CAT5 intensity. Although it is arguable that early CAT5 tropical cyclones were not detected because of the low population density in the region and the lack of direct geostationary satellite data prior to $1989^{16}$, post-1970 records globally have been largely standardised through satellite imagery to form the consolidated IBTrACS record. In the period 1970-1993, no tropical cyclones in the South Indian Ocean are recorded in the IBTrACS record to have intensified to CAT5, while such high intensity storms were recorded for other ocean basins. This 1994 record represents the latest global emergence of CAT5 tropical cyclones.

Secondly, between 1994 and 2015, a total of 12 CAT5 tropical cyclones are captured in the IBTrACS storm track records. Four of these storms occurred between 2010 and 2015, with a more recent CAT5 tropical cyclone in 2016 demonstrating consistency in storm intensification post-1994, and a slight, albeit statistically insignificant, increase in the frequency of CAT5 storms over time. This increase is consistent with a trend in the proportion of storms attaining CAT4 or CAT5, but at odds with the frequency of CAT4 and CAT5 storms in the South Indian Ocean ${ }^{16}$ This is a feature of a more rapid decline in CAT4 storms, potentially representing a greater percentage intensifying from CAT4 to CAT5 wind speed and central pressure.

Because of the low number of storms to date, the sample size is too small to detect any statistically significant trends. However, a poleward shift in the position of the storm track at intensification to and dissipation from CAT5 intensity is demonstrated through these 12 storms, concurrently with statistically significant poleward shifts in the $26.5^{\circ} \mathrm{C}$, $28^{\circ} \mathrm{C}$ and $29^{\circ} \mathrm{C}$ isotherms. These trends should be closely monitored to determine whether they represent persistent, long-term climatic change that supersedes inter-decadal patterns.

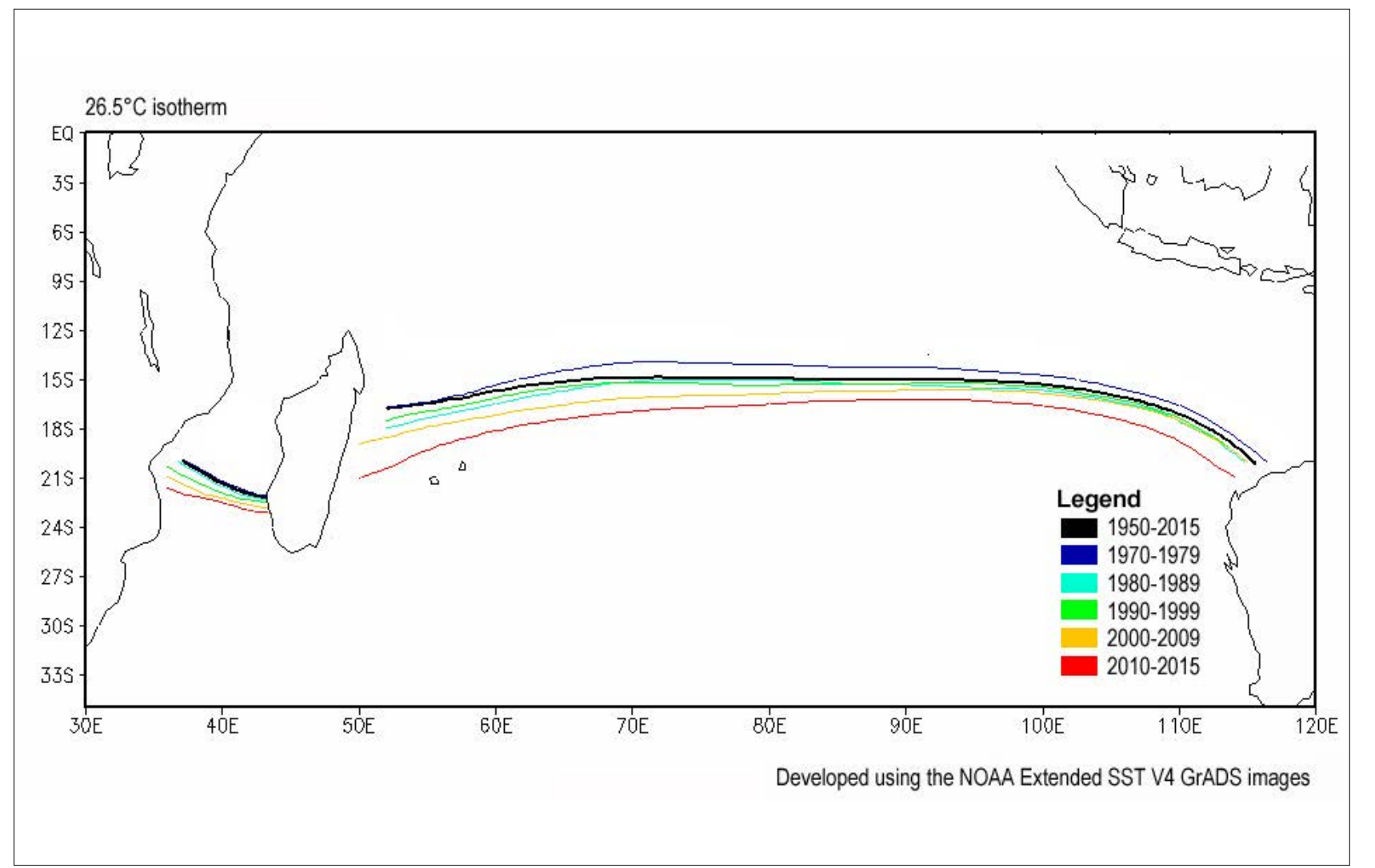

Figure 2: Decadal mean position of the $26.5^{\circ} \mathrm{C}$ sea surface temperature isotherm for the South Indian Ocean over the period $1970-2015$, relative to the 1950-2015 long-term mean (black line). 


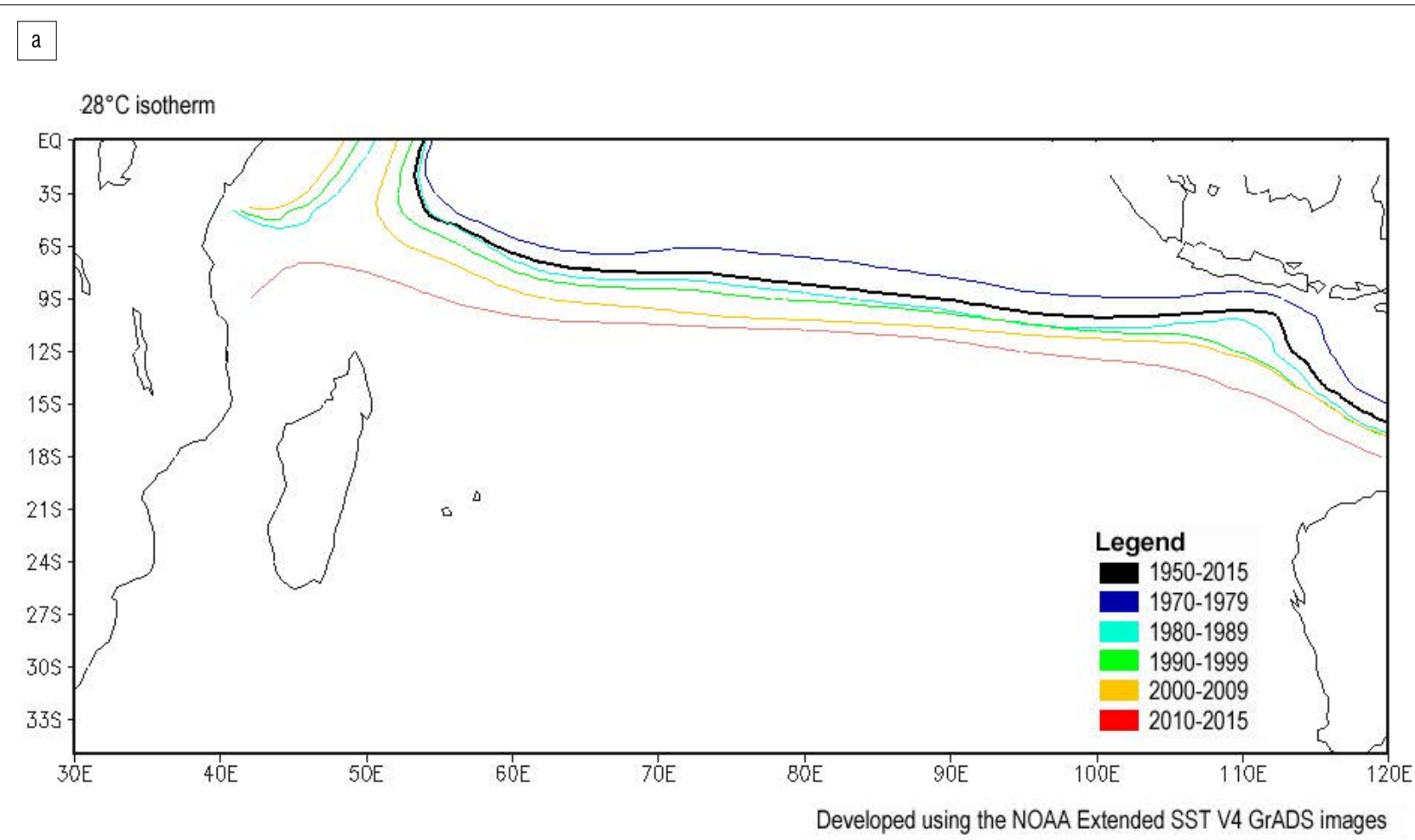

$\mathrm{b}$

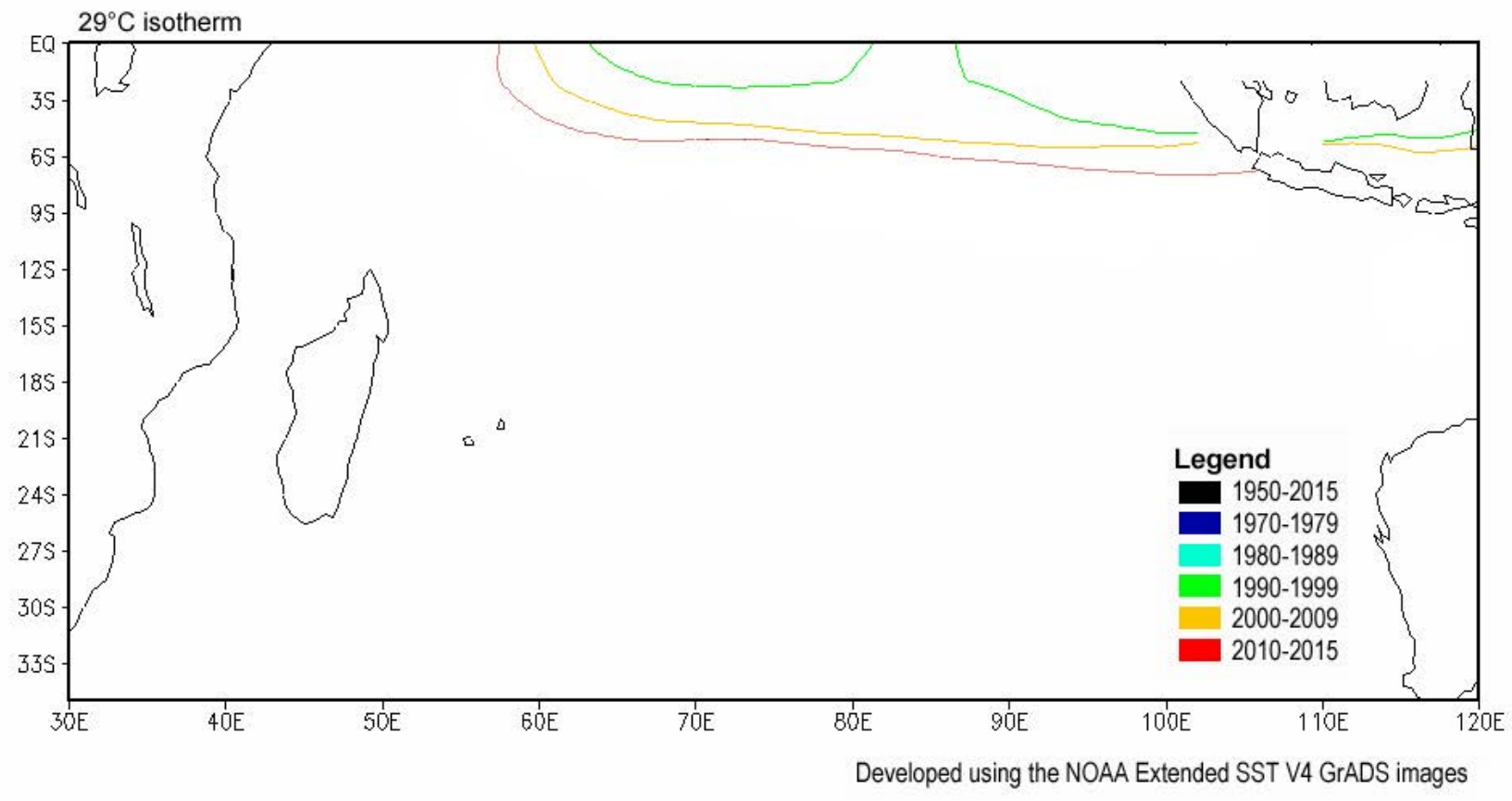

Figure 3: Decadal mean position of the (a) $28^{\circ} \mathrm{C}$ and (b) $29^{\circ} \mathrm{C}$ sea surface temperature isotherms for the South Indian Ocean over the period 1970-2015, relative to the 1950-2015 long-term mean (black line). 
Table 1: Summary of the CAT5 tropical cyclones recorded in the IBTrACS storm track database

\begin{tabular}{l|l|c|c|c|c}
\hline \hline Year & Storm name & $\begin{array}{c}\text { Date of } \\
\text { conversion }\end{array}$ & $\begin{array}{c}\text { Date of } \\
\text { dissipation }\end{array}$ & $\begin{array}{c}\text { Lowest } \\
\text { central } \\
\text { pressure }\end{array}$ & $\begin{array}{c}\text { Highest } \\
\text { speed }\end{array}$ \\
\hline \hline 2015 & Eunice & $2015-01-30$ & $2015-01-30$ & $910 \mathrm{mb}$ & $140 \mathrm{kts}$ \\
\hline 2015 & Bansi & $2015-01-13$ & $2015-01-13$ & $915 \mathrm{mb}$ & $140 \mathrm{kts}$ \\
\hline 2013 & Bruce & $2013-12-21$ & $2013-12-22$ & $920 \mathrm{mb}$ & $140 \mathrm{kts}$ \\
\hline 2010 & Edzani & $2010-01-08$ & $2010-01-09$ & $910 \mathrm{mb}$ & $140 \mathrm{kts}$ \\
\hline 2004 & Gafilo & $2004-03-06$ & $2004-03-07$ & $895 \mathrm{mb}$ & $140 \mathrm{kts}$ \\
\hline 2004 & Bento & $2004-11-23$ & $2004-11-24$ & $915 \mathrm{mb}$ & $140 \mathrm{kts}$ \\
\hline 2003 & Kalunde & $2003-03-08$ & $2003-03-08$ & $910 \mathrm{mb}$ & $140 \mathrm{kts}$ \\
\hline 2002 & Hary & $2002-03-10$ & $2002-03-10$ & $905 \mathrm{mb}$ & $140 \mathrm{kts}$ \\
\hline 1999 & Evrina & $1999-03-31$ & $1999-03-31$ & $920 \mathrm{mb}$ & $140 \mathrm{kts}$ \\
\hline 1996 & Itelle & $1996-04-14$ & $1996-04-14$ & $935 \mathrm{mb}$ & $140 \mathrm{kts}$ \\
\hline 1995 & Agnielle & $1995-11-21$ & $1995-11-21$ & $927 \mathrm{mb}$ & $150 \mathrm{kts}$ \\
\hline 1994 & Geralda & $1994-02-01$ & $1994-02-01$ & $905 \mathrm{mb}$ & $145 \mathrm{kts}$ \\
\hline
\end{tabular}

Table 2: $\quad$ Sea surface temperature $\left(\mathrm{SST},{ }^{\circ} \mathrm{C}\right)$ conditions for the South Indian Ocean CAT5 tropical cyclones

\begin{tabular}{l|l|c|c|c}
\hline \hline Year & Storm name & $\begin{array}{c}\text { SST at } \\
\text { conversion to } \\
\text { CAT1 }\end{array}$ & $\begin{array}{c}\text { SST at } \\
\text { conversion } \\
\text { to H5 }\end{array}$ & $\begin{array}{c}\text { SST at } \\
\text { dissipation } \\
\text { from H5 }\end{array}$ \\
\hline \hline 2015 & Eunice & 27.5 & 26.9 & 26 \\
\hline 2015 & Bansi & 27.9 & 27.7 & 27.7 \\
\hline 2013 & Bruce & 27 & 27.5 & 26 \\
\hline 2010 & Edzani & 27 & 26.2 & 26 \\
\hline 2004 & Gafilo & 28.65 & 28 & 27 \\
\hline 2004 & Bento & 28.5 & 27.8 & 27.2 \\
\hline 2003 & Kalunde & 29 & 28 & 27.9 \\
\hline 2002 & Hary & 29 & 28.5 & 28.5 \\
\hline 1999 & Evrina & 28 & 26.4 & 26.4 \\
\hline 1996 & Itelle & 27 & 26.8 & 26.2 \\
\hline 1995 & Agnielle & 27.1 & 27.5 & 27 \\
\hline 1994 & Geralda & 27.6 & 28.2 & 28.2 \\
\hline
\end{tabular}

The findings of this study rely heavily on the accuracy of the NOAA IBTrACS storm track database in capturing the intensity and latitudinal position of these CAT5 cyclones. These records provide an important global record of tropical cyclone activity, compiled for the period 18412015 through a combination of ship logs and land-based records for the early decades, and aerial reconnaissance and satellite imagery in more recent years. ${ }^{25}$ The record includes the storm track followed by the tropical cyclone, the intensity of the storm, and the factors from which intensity is derived: central storm pressure and wind speed. ${ }^{27}$ Concerns have been raised in the literature regarding the scientific accuracy of these records, and in particular issues of data heterogeneity as a result of the changing methods of storm identification and measurement. ${ }^{16,28,29}$ There is some consensus that records from 1970 onwards are relatively accurate because of the use of geo-orbiting satellites that provide constant monitoring across the global oceans, rather than the more sparse coverage temporally and spatially of passing ships or individual aeroplanes on reconnaissance missions, but concern has been raised that for the Indian Ocean, direct geo-orbiting satellite data were not available prior to the launch of Meteostat-5.11,16,27 Further efforts have been introduced to increase the accuracy of these records and their reanalysis data, with significant improvements reported ${ }^{27}$, and the IBTrACS records are now endorsed by the World Meteorological Organization $^{30}$. Furthermore, it is argued that the record is most accurate for storms at their maximum intensity: the storm has been in existence sufficiently long to be detected and monitored independently, and a greater impetus is placed on accurate recording as the storm develops a greater destructive potential. ${ }^{11}$ Thus for the purpose of this study, which focuses exclusively on CAT5 tropical cyclones subsequent to 1989 , the record is taken to be sufficiently reliable for calculating the findings presented.

CAT5 storms, which had not previously been recorded for the basin, occurred more frequently in the period 2010-2016 than in the previous decadal periods of 1990-1999 and 2000-2009. The Intergovernmental Panel on Climate Change has long suggested that climate change would result in an increased frequency and intensity of severe climatic events. ${ }^{1}$ For many of the world's ocean basins, trends over the past century have demonstrated little change in tropical cyclone numbers, and for regions such as the southwest Indian Ocean and West Pacific Ocean, a decreasing trend has been observed. ${ }^{8}$ This trend occurred concurrently with a $0.3{ }^{\circ} \mathrm{C}$ increase in mean global sea surface temperatures, which would encourage tropical cyclone formation. ${ }^{7}$ While it has been suggested that the intensity of tropical cyclones is increasing because of this warming trend, CAT5 storm dynamics have not previously been examined in isolation. ${ }^{11,15}$ The increase in the frequency of occurrence of CAT5 storms, particularly for a region that did not previously experience very high intensity tropical cyclones, demonstrates the manifestation of the sea surface temperature warming on tropical cyclone systems. This increase in frequency coupled with a net reduction in cumulative counts of CAT4 and CAT5 storms ${ }^{16}$ demonstrates that the storms previously terminating at CAT4 intensity are instead increasingly reaching CAT5 intensity - a feature further reflected in the increase in the percentage of CAT4 and CAT5 storms as a subset of all tropical cyclones, both in the South Indian Ocean and globally.

The warming trend in sea surface temperatures has resulted in a poleward shift in the South Indian Ocean $26.5^{\circ} \mathrm{C}$ isotherm required for tropical cyclone formation, at a statistically significant mean rate of $0.68 \%$ decade $(p<0.0001)$. More rapid is the poleward shift in the $28{ }^{\circ} \mathrm{C}$ isotherm, and the appearance and poleward migration of a $29^{\circ} \mathrm{C}$ isotherm in the South Indian Ocean over recent decades. These changes are occurring concurrently with a poleward shift in the latitude of the storm track position at the points of intensification to and dissipation from CAT5 for the 12 storms on record. Moreover, a distinct relationship appears to exist between the position of the $28^{\circ} \mathrm{C}$ and $29^{\circ} \mathrm{C}$ sea surface temperature isotherms and the probability of occurrence of CAT5 storms, as each of the recorded storms has occurred under conditions in which the $28^{\circ} \mathrm{C}$ isotherm is positioned south of $9^{\circ} \mathrm{S}$ latitude. These findings regarding the concurrent shifts in the $26.5^{\circ} \mathrm{C}, 28^{\circ} \mathrm{C}$ and $29^{\circ} \mathrm{C}$ isotherms and the latitudinal position of CAT5 storm tracks, and the sea surface temperature distributions characterising CAT5 storms, are important for future projection of storm trajectories and intensities, and for the shorterterm forecasting during the lifespan of a storm.

These results provide a concerning outlook for the South Indian Ocean. The region comprises a number of economically developing countries and small island states, which cannot afford large capital investment in infrastructural adaptation measures to mitigate against the threats of tropical cyclones. ${ }^{23,24}$ Unlike the United States of America, which experiences numerous tropical cyclones making landfall in any given year, only $5 \%$ of the $\sim 9$ tropical cyclones that form in the western half of the South Indian Ocean basin make landfall in any given year. ${ }^{8}$ However, all of the storms that make landfall have devastating impacts on the livelihoods, habitat, economy and natural environment of the country affected ${ }^{24}$ Thus, the threat of increasing proportions of the highest 
intensity tropical cyclones, even under scenarios involving an absolute reduction in storm numbers, is therefore potentially devastating. Furthermore, the poleward trajectory of these storms indicated by the 12 CAT5 tropical cyclones that have been recorded thus far, and global studies indicating a poleward trajectory in the lifetime maximum intensity of tropical storms ${ }^{11}$, pose a heightened threat for South Africa. Although the South African coastline is currently protected from tropical cyclones by Madagascar, this southward trajectory has the potential to heighten the proportion of storms tracking south of this island nation which currently takes the brunt of tropical cyclones in the South Indian Ocean. ${ }^{8,24}$ As one of the most economically important countries in subSaharan Africa, even infrequent storms pose the threat of catastrophic damage ${ }^{23}$ for South Africa. High intensity storms would not only increase the potential for damage through the heightened wind speeds and rainfall ${ }^{24}$, but storms of higher intensity additionally have a wider storm radius, increasing the region of damage on landfall. Considerable further monitoring of tropical cyclones in the region is warranted to confirm the trends identified from the IBTrACS storm track and GrADS V4 sea surface temperature imagery, and incorporate the findings into climate modelling efforts for the region.

\section{Acknowledgements}

This work was supported by a Society of South African Geographers Centennial Award for Emerging Career Researchers.

\section{References}

1. Intergovernmental Panel on Climate Change. Managing the risks of extreme events and disasters to advance climate change adaptation. A special report of Working Groups I and II of the Intergovernmental Panel on Climate Change. New York: Cambridge University Press; 2012.

2. Westra S, Fowler HJ, Evans JP, Alexander LV, Berg P, Johnson F, et al. Future changes to the intensity and frequency of short-duration extreme rainfall. Rev Geophys. 2014;52(3):522-555. https://doi.org/10.1002/2014RG000464

3. Fischer EM, Knutti R. Anthropogenic contribution to global occurrence of heavy-precipitation and high-temperature extremes. Nat Clim Change. 2015;5(6):560-564. https://doi.org/10.1038/nclimate2617

4. Perkins SE, Alexander LV, Nairn JR. Increasing frequency, intensity and duration of observed global heatwaves and warm spells. Geophys Res Lett. 2012;39(20), L20714, 5 pages. https://doi.org/10.1029/2012GL053361

5. Zhang $X$, Cong $Z$. Trends of precipitation intensity and frequency in hydrological regions of China from 1956 to 2005. Glob Planet Change. 2014;117:40-51. https://doi.org/10.1016/j.gloplacha.2014.03.002

6. Moore TW. A statistical analysis of the association between tropical cyclone intensity change and tornado frequency. Theor Appl Climatol. 2016;125(12):149-159. https://doi.org/10.1007/s00704-015-1501-3

7. Gouretski V, Kennedy J, Boyer T, Köhl T. Consistent near surface ocean warming since 1900 in two largely independent observing networks. Geophys Res Lett. 2012;39:1-8. https://doi.org/10.1029/2012GL052975

8. Fitchett JM, Grab SW. A 66-year tropical cyclone record for south-east Africa: Temporal trends in a global context. Int J Climatol. 2015;34(13):3604-3615. https://doi.org/10.1002/joc.3932

9. Malherbe J, Engelbrecht FA, Landman WA. Projected changes in tropical cyclone climatology in the Southwest Indian Ocean region under enhanced anthropogenic forcing. Clim Dynam. 2013;40:2867-2886. https://doi. org/10.1007/s00382-012-1635-2

10. Knutson TR, McBride JL, Chan J, Emanuel K, Holland G, Landsea C, et al. Tropical cyclones and climate change. Nat Geosci. 2010;3(3):157-163. https://doi.org/10.1038/ngeo779

11. Kossin JP, Emanuel KA, Vecchi GA. The poleward migration of the location of tropical cyclone maximum intensity. Nature. 2014;509(7500):349-352. https://doi.org/10.1038/nature13278

12. Henderson-Sellers A, Zhang H, Berz G, Emanuel K, Gray W, Landsea C, et al. Tropical cyclones and global climate change: A post-IPCC assessment. Bull Am Meteorol Soc. 1998;79(1):19-39. https://doi.org/10.1175/1520-0477
13. Yoshida K, Sugi M, Mizuta R, Murakami H, Ishii M. Future changes in tropical cyclone activity in high-resolution large-ensemble simulations. Geophys Res Lett. 2017;44(19):9910-9917. https://doi.org/10.1002/2017GL075058

14. Wing AA, Emanuel K, Solomon S. On the factors affecting trends and variability in tropical cyclone potential intensity. Geophys Res Lett. 2015;42(20):86698677. https://doi.org/10.1002/2015GL066145

15. Kuleshov Y, Fawcett R, Qi L, Trewin B, Jones D, McBride J, et al. Trends in tropical cyclones in the South Indian Ocean and the South Pacific Ocean. J Geophys Res Atmos. 2010;115(D1), Art. \#D01101, 9 pages. https://doi. org/10.1029/2009JD012372

16. Klotzbach PJ, Landsea CW. Extremely intense hurricanes: Revisiting Webster et al. (2005) after 10 years. J Clim. 2014;28:7621-7629. https://doi. org/10.1175/JCLI-D-15-0188.1

17. Matyas CJ. Tropical cyclone formation and motion in the Mozambique Channel. Int J Climatol. 2015;35(3):375-390. https://doi.org/10.1002/ joc.3985

18. Malherbe J, Engelbrecht FA, Landman WA, Engelbrecht CJ. Tropical systems from the southwest Indian Ocean making landfall over the Limpopo River Basin, southern Africa: A historical perspective. Int J Climatol. 2012;32(7):1018-1032. https://doi.org/10.1002/joc.2320

19. Astier N, Plu M, Claud C. Associations between tropical cyclone activity in the Southwest Indian Ocean and El Niño Southern Oscillation. Atmos Sci Lett. 2015;16(4):506-511. https://doi.org/10.1002/asl.589

20. Burns JM, Subrahmanyam B, Nyadjro ES, Murty VSN. Tropical cyclone activity over the Southwest Tropical Indian Ocean. J Geophys Res Oceans. 2016;121(8):6389-6402. https://doi.org/10.1002/2016JC011992

21. Ho CH, Kim JH, Jeong JH, Kim HS, Chen D. Variation of tropical cyclone activity in the South Indian Ocean: El Niño-Southern Oscillation and MaddenJulian Oscillation effects. J Geophys Res Atmos. 2006;111(D22), Art. \#D22101, 9 pages. https://doi.org/10.1029/2006JD007289

22. Tsuboi A, Takemi T, Yoneyama K. Seasonal environmental characteristics for the tropical cyclone genesis in the Indian 0cean during the CINDY2011/ DYNAM0 field experiment. Atmosphere. 2016;7(5):66. https://doi. org/10.3390/atmos7050066

23. Fitchett JM, Hoogendoorn G, Swemmer AM. Economic costs of the 2012 floods on tourism in the Mopani District Municipality, South Africa. Trans R Soc S Afr. 2016;71(2):187-194. https://doi.org/10.1080/003591 9X.2016.1167788

24. Nash DJ, Pribyl K, Klein J, Endfield GH, Kniveton DR, Adamson GC. Tropical cyclone activity over Madagascar during the late nineteenth century. Int J Climatol. 2015;35(11):3249-3261. https://doi.org/10.1002/joc.4204

25. Landsea C. Counting Atlantic tropical cyclones back to 1900. EOS. 2007;88(18):197-202. https://doi.org/10.1029/2007E0180001

26. Duvat VK, Volto N, Salmon C. Impacts of category 5 tropical cyclone Fantala (April 2016) on Farquhar Atoll, Seychelles Islands, Indian Ocean. Geomorphology. 2017;298:41-62. https://doi.org/10.1016/j. geomorph.2017.09.022

27. Landsea CW, Franklin JL. Atlantic hurricane database uncertainty and presentation of a new database format. Mon Weather Rev. 2013;141(10):3576-3592. https://doi.org/10.1175/MWR-D-12-00254.1

28. Walsh KJ, McBride JL, Klotzbach PJ, Balachandran S, Camargo SJ, Holland $\mathrm{G}$, et al. Tropical cyclones and climate change. WIRES Clim Change. 2016;7(1):65-89. https://doi.org/10.1002/wcc.371

29. Chan JC. Comment on "Changes in tropical cyclone number, duration, and intensity in a warming environment". Science. 2006;311(5768):1713. https://doi.org/10.1126/science.1121522

30. McTaggart-Cowan R, Galarneau Jr TJ, Bosart LF, Moore RW, Martius 0. A global climatology of baroclinically influenced tropical cyclogenesis. Mon Weather Rev. 2013;141(6):1963-1989. https://doi.org/10.1175/ MWR-D-12-00186.1 